\title{
Performance of Concrete Filled Steel Tube (CFST) Section: A Review
}

\author{
Vishal V. Gore ${ }^{1}$, Popat D. Kumbhar ${ }^{2}$ \\ ${ }^{1}$ PG Scholar, Department of Civil engineering, RIT Rajaramnagar, Sangli, Maharashtra, India \\ ${ }^{2}$ Associate Professor, Department of Civil engineering, RIT Rajaramnagar, Sangli, Maharashtra, India
}

\begin{abstract}
Concrete Filled Steel Tube (CFST) is the composite section formed by filling concrete into a hollow steel tube. The CFST section resists applied load through the composite action of concrete and steel, this advantageous interactive behavior between steel tubes and concrete increases the strength of CFST section and hence it has become popular in recent days and is being used in structures such as bridges, electricity towers, buildings etc. Extensive works carried out on CFST in past years have indicated that the CFST sections possess high ductility, strength and stiffness properties. These properties are considered to be important, especially for the multi-storied buildings required to be erected in earthquake prone areas. Therefore, behaviour of buildings with CFST sections needs to be studied. The present paper reviews various research works carried out by several researchers on CFST sections for investigating the behavior considering parameters such as length to diameter (L/D) ratio, Diameter to thickness $(\mathrm{D} / \mathrm{t})$ ratio, thickness of steel tube etc.
\end{abstract}

Keywords: Concrete Filled Steel Tube (CFST), Finite Element Model, D/t ratio, L/D ratio, thickness of steel tube.

\section{Introduction}

Concrete Filled Steel Tube (CFST) sections are one of the best composite sections which have many advantages over conventional steel and $\mathrm{RC}$ sections and hence these CFST sections are becoming more popular in recent year[1]. The CFST sections are formed by filling concrete into a hollow steel tube section and offers resistance to applied load through the composite action of steel and concrete [2]. In CFST section the steel tube act as longitudinal as well as transverse reinforcement [3]. The steel tube in CFST section lies at the outer perimeter, which effectively resist tension and bending moments and also increases stiffness of CFST section as steel has a high modulus of elasticity. The inner concrete core of CFST section also plays an important part in delaying the inward buckling of steel tube and improves the behavior of CFST section [4,5]. Steel tube in CFST also

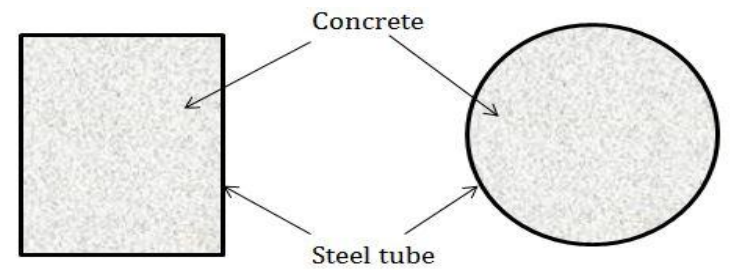

(a) Regular CFST section

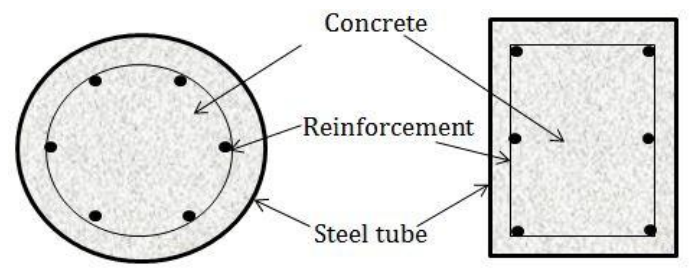

(b) CFST section with reinforcement

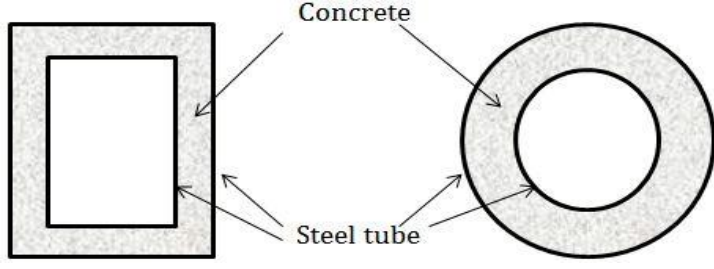

(c) Concrete filled double skin tubes

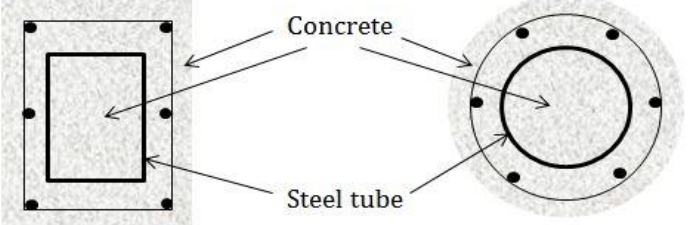

(d) Concrete encased CFST section

Figure 1: Types of CFST section

provides good confinement to the inner concrete core, which increases the compressive strength of the CFST section [6]. Thus, CFST sections are advantageous where the columns are subjected to large compressive forces. CFST section possesses high ductility, strength, and energy absorption capacity which are very important for a structure located in earthquake prone areas [7, 8].CFST sections have additional advantage that the steel tube of the section serves as a form work during construction, thus helps in saving additional cost required for formwork and also the time required for construction [9]. Based on the shape of cross-section, CFST sections are classified into various types namely regular CFST section [Fig-1a], CFST section with reinforcement [Fig-1b], concrete filled double skin tubes[Fig-1c], and concrete encased CFST section[Fig-1d] [10].

\section{Present studies and theories}

There are many researches have been carried out on CFST section for investigating its behavior with considering parameters like grade of concrete, cross-sectional shape, 


\section{International Journal of Science and Research (IJSR) \\ ISSN (Online): 2319-7064}

Index Copernicus Value (2013): 6.14 | Impact Factor (2014): 5.611

Diameter to thickness $(\mathrm{D} / \mathrm{t})$ ratio and length to width $(\mathrm{L} / \mathrm{D})$ ratio. This section summarizes various studies carried out on CFST section.

Lia-Hai Han et al. (2011), have investigated the tensile behaviour of CFST section considering parameters such as steel ratio and type of concrete. Tensile behaviour of CFST section was examined by experimentally as well as developing a finite element model. The study found that the tensile strength of CFST section is more than the hollow steel tube and it was further increased by filling SFRC concrete into steel tube. Researchers had also proposed a simplified formula for calculating tensile strength of CFST section and it gives good agreement between calculated and tested results.

Y. F. Yang, L. H. Han (2012), have examined the behavior of CFST under partial compression by considering different parameters, namely cross sectional shape, length to diameter ratio and partial compression area ratio. The study was carried out by testing twenty-six specimens of CFST by varying the above parameters and their behavior was also verified by developing a finite element model using ABAQUS software. The study shows that the behaviour of partial compressed CFST section is similar to the behaviour of fully compressed CFST section. Also, it is possible to predict strength of partial compressed CFST section using mathematical model proposed by researchers.

Chen Shiming, Zhang Huifeng (2012), studied the compressive behavior of circular CFST section with provision of the separation gap between inner concrete core and steel tube. Study is carried out with different parameters such as gap depth, strength of concrete, yield stress of steel, thickness of steel tube and eccentricity of the load. The Finite Element model is developed by using ABAQUS software and their results are compared with test results. The results indicate that the strength of CFST section decreases with increasing depth of the gap and eccentricity of the load. Also, it is observed that the thickness of steel tube helps to improve the strength of CFST section due to confinement effect.

Farid Abed et al. (2013), studied the compressive behaviour of circular CFST column filled with different concrete grades and varying $\mathrm{D} / \mathrm{t}$ ratios. The experimental results of study were compared with analytical method proposed by various codes namely EC-4,ACI-318,AISC-2005and AS. From these studies researchers have concluded that for higher $\mathrm{D} / \mathrm{t}$ ratio, reduction in compressive strength of CFST section occurs due to less confinement. The study also shows that for the higher $\mathrm{D} / \mathrm{t}$ ratio there is less deviation observed in experimental and analytical results. Experimental results of this study were also verified using ABAQUS software and there is found to be a good agreement in-between both results.

K. Kalingarani et al. (2014), investigated the compressive behavior of slender CFST columns by analytically using various available codes, namely EC4, ACI-318 and AISC2005.The study was carried out by varying diameter to thickness $(\mathrm{D} / \mathrm{t})$ and length to width (L/D) ratio. Analytical results obtained by using codal method indicates that for an increased $\mathrm{D} / \mathrm{t}$ ratio keeping diameter constant, compressive strength of CFST section was decreased due to less confinements also reduction in compressive strength occurs for increased L/D ratio due to slenderness effect.

B. R. Niranjan, Eramma H.(2014), studied the compressive behavior of triangular and rectangular fluted reinforced circular CFST column with varying length to width (L/D) ratio. The compressive strength of CFST columns were obtained by experimentally and analytically. Analytical results of CFST column calculated using codes EC-4, ACI318 and AISC. In this study the experimental strength results of CFST columns were founds higher than the analytical strength results calculated from methods given in above codes; hence the researchers had suggested that the equations given in above codes cannot be directly used to calculate the compressive strength of the fluted CFST column.

Burak Evirgen et al. (2014), they investigated the compressive behavior of CFST section considering various cross-sectional shapes like circular, hexagonal, rectangular and square. Experimental study was carried out by varying $\mathrm{B} / \mathrm{t}$ (Breadth to thickness) ratio and grades of concrete. The obtained results of experimental study were compared with software results calculated by developing a finite element model using ABAQUS software. In this study, researchers observed that the concrete core of CFST resists the inward buckling of steel tube and steel tube provides better confinement to concrete core which results increase in the strength of CFST section. The study also shows that the ductility of the circular CSFT section is more than hexagonal, rectangular and square CFST sections.

M. F. Hassanein, O. F. Kharoob (2014), studied the compressive behaviour of double skin concrete filled steel tube circular short columns with varying diameter to thickness $(\mathrm{D} / \mathrm{t})$ ratio. In this study many previously developed equations were referred to calculate the strength of Concrete Filled Double Skin Tube (CFDST). Obtained results of these equations were compared with test results and by developing a finite element model using ABAQUS software. After comparison, it was found to be a less agreement in-between both analytical and experimental result values, hence researchers had derived new equation for finding strength of the CFDST short column.

X. H. Dai et al. (2014), investigated the compressive behavior of elliptical slender CFST section. A Complete behavioral study carried out by developing a finite element model using ABAQUS software and these software results of elliptical CFST sections compared with several test results for validation and accuracy. The researchers have also calculated the buckling load of elliptical section according to the specification given in Euro Code -4 for rectangular and circular CFST section and it is concluded that the design method given in EC-4 for finding the axial compression behavior of circular and rectangular CFST section may be used for the elliptical CFST section.

Qing-Xin Ren et. al. (2014), examined the compressive behavior of CFST stub column considering special-shaped cross section, namely triangular, fan shaped, D-shaped, 1/4

\section{Volume 4 Issue 11, November 2015}




\section{International Journal of Science and Research (IJSR) \\ ISSN (Online): 2319-7064}

Index Copernicus Value (2013): 6.14 | Impact Factor (2014): 5.611

circular and semicircular for constant outer perimeter. This study mainly focused on the effect of thickness of steel tube and infill concrete on the behavior of composite column. There were about 44 specimens tested of special-shaped cross section including a hollow steel tube section. Test results are also compared with the results of Eurocode- 4 and $\mathrm{DBJ} / \mathrm{T} 13-51-2010$ and found reasonable variations. It is shown in this study that the failure of special sections was also occurred due to outward buckling in the middle of section. This study also shows that the strength of special cross sections was increased in the order of triangular, semicircular, fan shaped, D-shaped, $1 / 4$ circular and circular sections.

\section{Conclusions}

Based on the studies so far carried out by several researchers following conclusions can be drawn.

1. From the review of the studies carried out by various researchers it can be concluded that as $\mathrm{D} / \mathrm{t}$ ratio of CFST section increases, reduction in compressive strength occurs due to less confinement.

2. As CFST section provide high ductility, strength and stiffness properties which are important in resisting earthquake forces hence the seismic behavioral study of structure using CFST section becomes essential.

\section{References}

[1] Artiomas Kuranovas, Audronis Kazimieras Kvedaras, "Behavior of hollow concrete-filled steel tubular composite elements", Journal of Civil Engineering and Management, vol.13, pp 131-141, 2007.

[2] M. F. Hassanein, O. F. Kharoob, "Compressive strength of circular concrete-filled double skin tubular short columns", Thin Walled Structure, vol.77, pp.165-173, 2014.

[3] K.Kalingarani, B. Shanmugavalli, M.C. Sundarraja "Axial Compressive Behavior of Slender CFST members-Analytical Investigation", International Journal of Innovative Research in Science, Engineering and Technology, vol. 3, pp-22-25, 2014.

[4] Burak Evirgen, Ahmet Tuncan, Kivanc Taskin "Structural behavior of concrete filled steel tubular sections (CFT/CFST) under axial compression", Thin Walled Structure, vol.80, pp 46-56, 2014.

[5] F.W. Lu, S.P. Li, Guojun Sun, "A study on the behavior of eccentrically compressed square concrete-filled steel tube columns", Journal of constructional Steel Research, vol.63, pp941-948. 2006.

[6] Farid Abed, Suliman Abdalla, "Experimental and numerical investigations of the compressive behavior of concrete filled steel tubes (CFST)", Journal of constructional Steel Research, vol.80, pp 429-439. 2013.

[7] X.H. Dai, D. Lam, N. Jamaluddin, "Numerical analysis of slender elliptical concrete filled columns under axial compression", Thin Walled Structure, vol.77, pp 26-35, 2014.

[8] B.R.Niranjan, H. Eramma "Comparison of Experimental values with EC 4, ACI-318, AISC-LRFD of Concrete Filled Steel Fluted Columns for Concentric Load"
American Journal of Engineering Research , vol. 3, pp335-344, 2014

[9] Chen Shiming, Zhang Huifen, "Numerical analysis of the axially loaded concrete filled steel tube columns with debonding separation at the steel-concrete interface", Steel and Composite Structures, vol. 13, pp. 1-17, 2012.

[10]L. H. Han, Wei Li, "Developments and advanced applications of concrete-filled steel tubular (CFST) structures: Members", Journal of constructional Steel Research,Vol.100, pp 211-228,2014.

\section{Author Profile}

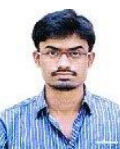

Vishal V. Gore, PG Scholar (Civil Structure) Department of Civil Engineering, RIT Rajaramnagar, Sangli, Maharashtra, India.

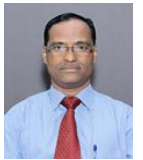

Popat D. Kumbhar, Associate Professor, Department of Civil Engineering, RIT Rajaramnagar, Sangli, Maharashtra, India. 